\title{
In Vivo Evaluation of Genotoxic Effect of Caralluma acutangula (Decne.) N.E.Br. extract on Mice Bone Marrow Cells
}

\author{
Zarraq I. A. Al-Faifi \\ Biological Science Department, Faculty of Science, Jazan University, Jazan, Saudi Arabia
}

\section{ABSTRACT}

The current study was designed to evaluate the genotoxicity of Caralluma acutangula (Decne.) N.E.Br. extract on mice bone marrow cells in vivo. Two cytogenetics parameters were used, chromosomal aberrations assay and micronucleus test. Three different concentrations 125, 250, and $500 \mathrm{mg} / \mathrm{kg}$ body weight were chosen. Our results demonstrated that administration of C. acutangula extract did not significantly increase the number of structural chromosomal aberrations. No significant differences in the percentages of mitotic indices were observed at the three different concentrations of $C$. acutangula extract. In micronucleus test, treatment with $C$. acutangula extract caused no significant increase in the number of polychromatic erythrocytes with micronuclei or in the mean percentage of polychromatic. In conclusion, $C$. acutangula extract showed no significant genotoxic effect on mice bone marrow cells in vivo.

Keywords: Caralluma acutangula, genotoxicity, clastogenicity, micronuclei, chromosomal aberrations.

\section{Corresponding author:}

Zarraq I. A. Al-Faifi, Biology Department, Faculty of Science, Jazan University, PO Box 2097, Jazan 45142, Saudi Arabia.

E-mail: z_alfifi@hotmail.com

\section{INTRODUCTION}

Traditional medicine has remained the most affordable and easily accessible treatment in the primary healthcare system in rural and remote areas around the world, and local treatment is the only means of treatment medicine for such communities. In Africa, Asia, Latin America and the Middle East, 70-95 percent of the population still use traditional medicine (TM) for primary healthcare. And some 100 million people are believed to use traditional, complementary or herbal medicine in the European Union (EU) alone - as high as 90 percent of the population in some countries (Robinson and Zhang, 2011). Assessment of the potential genotoxicity of traditional medicines is a critical issue as damage to the genetic material may lead to critical mutations and therefore also to an increased risk of cancer and other diseases. Genetic toxicology studies have given rise to many testing procedures, both in vitro and in vivo. These procedures have been designed to assess the effects of various test substances on the genetic material and consequently, to assess the risk to living organisms including humans (Attia, 2011). Testing in vivo on rodents have been used because the metabolic activation and detoxification of the chemicals in the animals are closer to human system. The micronucleus test detects clastogenicity due to chromosome breakage (Attia, 2007), and aneugenicity due to chromosome lagging resulting from imbalances in the mitotic apparatus (Rojas et al., 1993). Alterations in cells such as chromosomal aberrations (CAs) 
and sister chromatid exchanges (SCE) have long been applied in surveillance of human genotoxic exposure and early effects of genotoxic carcinogens. The use of these biomarker assays is based on the fact that most established human carcinogens are genotoxic in short-term tests and capable of inducing chromosomal damage. On the other hand, chromosomal aberrations have been used as important cytogenetic biomarkers to study the mutagenic effects of different chemicals in vivo and in vitro, The relevance of CAs as a biomarker has been further emphasized by epidemiological studies suggesting that a high frequency of chromosomal aberrations is predictive of an increased risk of cancer (Sutiakova et al., 2012). On the other hand, SCE is a highly sensitive parameter for evaluating human occupational and environmental exposure to mutagenic and carcinogenic agents, Moreover, parameters such as Mitotic Index (MI) and Cell Proliferation kinetics (CPK) have been proposed as useful biomarkers for the pre-screening of the potential cytostatic activity of new drugs. The use of the cell proliferation kinetics and the mitotic index are recognized biomarkers in biological monitoring to evaluate cellular proliferation in population as well as to evaluate normal or tumor cells (Norppa et al., 2006). Moreover, chromosomal aberrations micronucleus test have been known as sensitive methods of genetic toxicity tests of plant extracts both in vivo and in vitro (Chakrabati, 2001).

The South-West region of Saudi Arabia is rich in wild plants representing about $70 \%$ of total flora of Saudi Arabia. Apocynaceae is one of the largest plant families in the area with many species that are used to treat diseases by traditional medicine practitioners of Saudi Arabia (Rahman et al., 2004).

The genus Caralluma belongs to the family Apocynaceae (subfamily Asclepiadoideae), which consists of about 250 genera and 2600 species. The plants belong to this genus are rich in pregnane glycosides, some of which showed antitumor activity (Deepak et al., 1997). Certain species of Caralluma are edible and form part of the traditional medicine system for many countries (Abdel-Sattar et al., 2007). These common types used in folk medicine as a remedy for treating a wide range of diseases and health conditions (Ahmad et al., 1983).

In Saudi Arabia, this genus is represented by 14 species found in West and South-West regions (Chaudhary, 2001). Caralluma has significant anti-inflammatory activity, antinociceptive activity and antitumor activity (Deepak et al., 1997; Ramesh et al., 1999; Zakaria et al., 2001, Rao et al., 1998, Albalawi et al., 2015; Priya et al., 2014), cytoprotective and antiulcer activity (Al-Harbi et al., 1994; Zakaria et al., 2002), antioxidant, hypolipidemic (Tatiya et al., 2010), antihyperglycemic (Venktesh et al., 2003), antidiabetic (Wadood et al., 1989), treating joint pains, paralysis, and antipyretic (Khan and Khatoon, 2008). Some species have been used as traditional and modern dietary ingredients to suppress appetite (Lawrence and Choudhary, 2004; Dutt et al., 2011). To date, there are no scientific studies on genotoxic effects of $C$. acutangula. Therefore, we designed the current study to assess the impact of genetic toxicity of $C$. acutangula extract using two cytogenetics end points, chromosomal aberrations and micronucleus assays in mice bone marrow cells in vivo.

\section{MATERIALS AND METHODS}

\section{Collection of plant material:}

Mature Caralluma acutangula plants were collected from different locations from South-West region of Saudi Arabia and was identified by Dr. Yahya Masrahi, (Biological Science Department, Faculty of Science, Jazan University, Jazan, Saudi Arabia). 


\section{Extraction:}

The plant was washed and dried. Then, it was grinded to fine powder, passed through a 24-mesh sieve, weighted, and stored at room temperature. The powdered sample $(30 \mathrm{~g})$ of $C$. acutangula was extracted with $300 \mathrm{ml}$ of methanol using magnetic stirrer and stir $3 \mathrm{hrs}$ at room temperature. The extract was then filtered using Whatmann No. 1 filter paper. The residue was dissolved in $300 \mathrm{ml}$ methanol and stirred for $3 \mathrm{hrs}$. The solvent containing the extract was dried under reduced pressure. An aqueous extract was also prepared using $20 \mathrm{~g}$ powdered sample in $200 \mathrm{ml}$ distilled water and stir $3 \mathrm{hrs}$ at room temperature. The supernatant was boiled up to minimum volume.

\section{Animals}

Experimental study was carried out using albino mice, weighing 25-30 g. The animals were randomly assigned to different control and treatment groups (five animals in each group) that were maintained under standard conditions of humidity, temperature and light (12hr light/12hr dark), with free access to laboratory diet chow and tap water. The Institutional Animal Ethics Committee at Biological Science Department of Faculty of Science, Jazan University has approved the study.

\section{Chromosomal preparation:}

Chromosomal preparations were made according to the method described previously (Preston et al., 1987). Colchicine ( $2.5 \mathrm{mg} / \mathrm{kg}$ body weight) was injected intraperitoneally. Animals were sacrificed by cervical dislocation $2 \mathrm{hr}$ after colchicine injections. The bone marrow cells were flushed out with buffer solution $(\mathrm{pH}=7)$ from both femurs. The cells were centrifuged for 10 minutes at 1000 r.p.m. After centrifugation, the supernatant fluid was discarded, and the cells were resuspended in prewarmed hypotonic $0.56 \% \mathrm{KCl}$ solution, incubated at $37^{\circ} \mathrm{C}$ for 25 minutes and centrifuged for 10 minutes at 1000 r.p.m. Cells were then fixed in freshly prepared Carnoy's fixative (3:1 methanol-glacial acetic acid) for 20 minutes. Fixative was changed two times. Few drops of the final suspension were dropped on clean icecold slides. During dropping, the slides were placed on hot plate, air-dried and stained with Giemsa stain. For each animal, at least 50 metaphases were analyzed for chromosomal aberrations using light research microscope with $1000 \mathrm{X}$ magnification.

\section{Micronucleus test (MNT):}

Bone marrow smears were prepared according to the method described previously (Schmid, 1975). Bone marrow cells were flushed out in fetal calf serum, then centrifuged for 10 minutes at 1500 r.p.m., the supernatant fluid was removed and the sedimented cells were resuspended in few drops of fetal calf serum. Bone marrow cells was then smeared on a clean, dry slide. Slides were aged overnight and fixed in $70 \%$ methyl alcohol for 15 minutes. The slides were then stained for 10 minutes using Giemsa stain, rinsed in distilled water, blotted with filter paper and examined. For micronucleus assay, 2000 polychromatic erythrocytes (PCEs) were examined under $1000 \mathrm{X}$ objective lens research microscope. The micronucleated PCEs were registered. A total of about 1000 erythrocytes of both types PCEs and NCEs were counted for each animal to determine the PCEs/NCEs ratio.

\section{Statistical analysis:}

Incidence of abnormal metaphases and micronucleated cells were analyzed for significance using Student's t- test. 


\section{RESULTS}

\section{Chromosomal aberrations:}

Table (I) shows the frequency of chromosomal aberrations induced in mouse bone marrow cells after single oral dose administration of $C$. acutangula extract at 125,250 and $500 \mathrm{mg} / \mathrm{kg}$ body weight after 24 hr. The chromosomal aberration data were evaluated as the percentage of aberrant metaphase cells (including and excluding gaps). No significant increase in different types of chromosomal aberrations was detected compared with vehicle control group. Whereas, cyclophosphamide treated animals showed significant increase $(\mathrm{p}<0.001)$ in different types of chromosomal aberrations (Table 1$)$.

Table 1: Different types of chromosomal aberrations in mouse bone-marrow cells after $24 \mathrm{hr}$. of treatment.

\begin{tabular}{|c|c|c|c|c|c|c|c|c|c|c|c|c|c|}
\hline \multirow[t]{3}{*}{ Treatment } & \multirow{2}{*}{\multicolumn{7}{|c|}{$\begin{array}{l}\text { Structural chromosomal } \\
\text { aberrations } / 300 \text { cells }\end{array}$}} & \multicolumn{6}{|c|}{ No. of abnormal metaphases } \\
\hline & & & & & & & & \multicolumn{3}{|c|}{ With gaps } & \multicolumn{3}{|c|}{ Without gaps } \\
\hline & $\begin{array}{l}\mathrm{C} \\
\mathrm{g}\end{array}$ & d & $\mathbf{R}$ & $\begin{array}{c}\text { e to } \\
\text { e a } \\
\text { and/ } \\
\text { or } r\end{array}$ & $\begin{array}{c}\text { a f } \\
\text { and/ } \\
\text { or b }\end{array}$ & $\begin{array}{c}\text { di } \\
\text { c }\end{array}$ & $\begin{array}{c}\text { More } \\
\text { than one } \\
\text { type of } \\
\text { aberrati } \\
\text { ons }\end{array}$ & $\begin{array}{l}\mathbf{N} \\
\mathbf{0 .}\end{array}$ & $\begin{array}{c}\text { Means } \\
\%\end{array}$ & $\pm \mathbf{S E}$ & $\begin{array}{l}\mathbf{N} \\
\mathbf{0 .}\end{array}$ & $\begin{array}{c}\text { Means } \\
\%\end{array}$ & $\pm \mathrm{SE}$ \\
\hline $\begin{array}{l}\text { Vehicle } \\
\text { control }\end{array}$ & $\begin{array}{l}1 \\
2\end{array}$ & 4 & 5 & 1 & 2 & 7 & 10 & 41 & 22.77 & 0.601 & 29 & 16.11 & 0.307 \\
\hline $\begin{array}{l}\text { Cyclophospha } \\
\text { mide }\end{array}$ & $\begin{array}{l}3 \\
5\end{array}$ & 7 & 9 & 8 & 6 & $\begin{array}{l}2 \\
6\end{array}$ & 15 & $\begin{array}{l}10 \\
6\end{array}$ & 58.89 & $\begin{array}{l}0.988 * \\
* *\end{array}$ & 71 & 39.4 & $\begin{array}{l}1.222 * \\
* *\end{array}$ \\
\hline $\begin{array}{l}\text { C. acutangula } \\
\text { extract } 125 \\
\mathrm{mg} / \mathrm{kg}\end{array}$ & $\begin{array}{l}1 \\
0\end{array}$ & 3 & 4 & 1 & 1 & 4 & 5 & 28 & 19.78 & 0.403 & 23 & 15.01 & 0.211 \\
\hline $\begin{array}{l}\text { C. acutangula } \\
\text { extract } 250 \\
\mathrm{mg} / \mathrm{kg}\end{array}$ & $\begin{array}{l}1 \\
1\end{array}$ & 4 & 3 & 0 & 2 & 5 & 6 & 25 & 17.67 & 0.333 & 20 & 15.11 & 0.201 \\
\hline $\begin{array}{l}\text { C. acutangula } \\
\text { extract } 500 \\
\mathrm{mg} / \mathrm{kg}\end{array}$ & $\begin{array}{l}1 \\
2\end{array}$ & 3 & 4 & 2 & 2 & 4 & 6 & 33 & 20.21 & 0.521 & 27 & 16.34 & 0.289 \\
\hline
\end{tabular}

$\mathrm{Cg}=$ chromatid and/or chromosomal gap $\mathrm{d}=$ deletion $\mathrm{R} \mathrm{T}=$ Robertsonian translocation e to e $\mathrm{a}=$ end to end association $\mathrm{r}=$ ring a $\mathrm{f}=$ acentric fragment $\mathrm{b}=$ break dic=dicentric $* * * \mathrm{p} \leq 0.001=$ very highly significant

\section{Micronucleus test}

Frequency and percentage of MNPCE, and percent of PCE were shown in (Table 2). Animals treated with cyclophosphamide showed a significant increase $(\mathrm{p}<0.001)$ in the average number and percentage of MNPCE, and percent of PCE when compared to the control group. Animals treated with different concentrations of $C$. acutangula extract showed no significant increase in the mean number or percentage of MNPCE and in the percentage of PCE when compared with control group. 
Table 2: Frequency and percentage of MNPCE, and Percentage of PCE after treatment with Caralluma acutangula Extract

\begin{tabular}{|l|l|l|l|}
\hline Treatment & MNPCE/2000 & $\begin{array}{l}\text { Percentage of } \\
\text { MNPCE }\end{array}$ & $\begin{array}{l}\text { Percentage of } \\
\text { PCE }\end{array}$ \\
\hline Vehicle control & $2.11 \pm 0.29$ & $0.12 \pm 0.01$ & $46.31 \pm 1.9$ \\
\hline Cyclophosphamide & $13.5 \pm 1.23^{* * *}$ & $0.67 \pm 0.05 * * *$ & $65.99 \pm 2.03^{* * *}$ \\
\hline $\begin{array}{l}\text { C. acutangula } \\
\text { extract } 125 \mathrm{mg} / \mathrm{kg}\end{array}$ & $1.9 \pm 0.34$ & $0.09 \pm 0.01$ & $49.34 \pm 1.3$ \\
\hline $\begin{array}{l}\text { C. acutangula } \\
\text { extract } 250 \mathrm{mg} / \mathrm{kg}\end{array}$ & $2.7 \pm 0.31$ & $0.13 \pm 0.01$ & $50.95 \pm 1.33$ \\
\hline $\begin{array}{l}\text { C. acutangula } \\
\text { extract } 500 \mathrm{mg} / \mathrm{kg}\end{array}$ & $2.9 \pm 0.39$ & $0.16 \pm 0.02$ & $51.9 \pm 0.84$ \\
\hline
\end{tabular}

$* * * \mathrm{p} \leq 0.001=$ very highly significant

\section{Mitotic index}

The percentage of mitotic index used to determine the rate of cell division. No significant differences in the percentages of mitotic indices were observed at the three different concentrations of $C$. acutangula extract. Cyclophosphamide treated animals showed a significant decrease $(\mathrm{p}<0.001)$ in percentage of mitotic index when compared with control group (Table 3).

Table 3: Effect of $C$. acutangula extract on the Mitotic index after $24 \mathrm{~h}$ of Treatment.

\begin{tabular}{|l|c|c|c|}
\hline \multicolumn{1}{|c|}{ Treatment } & No. of non-dividing cells & No. of dividing cells & Mitotic Index \% \\
\hline Vehicle control & $866.30 \pm 24.33$ & $131.70 \pm 24.33$ & $15.24 \pm 3.15$ \\
\hline Cyclophosphamide & $976.20 \pm 6.02$ & $23.80 \pm 6.02$ & $2.44 \pm 0.63^{* * *}$ \\
\hline C. acutangula extract $125 \mathrm{mg} / \mathrm{kg}$ & $887.70 \pm 8.95$ & $112.30 \pm 8.96$ & $12.66 \pm 1.13$ \\
\hline C. acutangula extract $250 \mathrm{mg} / \mathrm{kg}$ & $858.70 \pm 9.82$ & $141.30 \pm 9.82$ & $16.47 \pm 1.33$ \\
\hline C. acutangula extract $500 \mathrm{mg} / \mathrm{kg}$ & $873.2 \pm 9.30$ & $126.8 \pm 9.35$ & $16.57 \pm 1.23$ \\
\hline
\end{tabular}

$* * * \mathrm{p} \leq 0.001=$ very highly significant

\section{DISCUSSION}

In the present study, the chromosomal aberration and micronucleus assay were cooperatively used to study the genotoxic effect of $C$. acutangula extract against cyclophosphamide induced genotoxicity at a chromosomal level, micronuclei level for $24 \mathrm{~h}$. It has been reported that genotoxic chemicals in general produce the highest frequency of aberrations in rodents $24 \mathrm{~h}$ after single exposure, which roughly coincides with the normal length (22-24 h) of the cell cycle (Adler, 1984; Hayashi et al., 1984). Three genotoxicity evaluation methods cover different aspects of genotoxic events. Bone marrow chromosomal aberration is one of the most effective and sensitive short-term in vivo bioassay that utilizes cytological damage as an end-point in detecting and screening chemical agents that induce clastogenicity (Sanchez et. al., 1988).

Chromosome analysis of bone marrow cells in vivo is a standard method for testing for the potential mutagenic effects (Celik et. al., 2003). The micronucleus assay detects chromosomal damage that persists 
for at least one mitotic cycle (Zhong et. al., 2001). Some of the DNA lesions, such as single and double strand breaks, and adduct formation, led to permanent fetal damage, and the micronucleus test is an excellent means of evaluating any permanent damage in genetic material.

Genotoxic factors may cause genetic damage in any cell of the body. In case of damage, in somatic cells, it could lead to cancer or maybe some degenerative diseases in individuals at risk. Anti-genotoxicity studies are related directly to the protective role of factors related to the genetic material. There are many reports on the investigation of anti-genotoxicity using chromosomal aberration test and micronuclei assay (Shetty et al., 2010). Mutagenicity testing has been recognized as an essential part in evaluating the genotoxicity of plant extracts. This interesting idea of utilizing nuclear anomalies in bone marrow cells as a rapid method to analyze the mutagenic potential of plant extracts, provide an incentive for others who work in the field of mutation (Al-Azzawi, 2012). The rodent (mouse and rat) micronucleus assay was performed to assess the correlation between micronucleus induction and human carcinogenicity in vivo (Morita et al., 1997).

It is acknowledged that an increase in the frequency of chromosomal aberrations in bone marrow cells is associated with an increased overall risk of cancer (Hagmar et. al., 1994). An increase in chromosomal aberrations may result from interactions of a wide range of chemical agents with DNA. According to Ishidate et al. (1988), the agents which induce an increase in the chromosomal aberrations frequency by direct or indirect mechanism may also be cytotoxic, for damage to both DNA and other cell targets (enzymes, membranes, structural proteins). Chromosomal aberrations and sister chromatid exchanges are extremely valuable and highly relevant endpoints for the detection of potential carcinogens (Swierenga $e t$ al., 1991). Most of the chromosomal aberrations observed in the cells are lethal, but there are many other aberrations that are viable and cause genetic effects, either somatic or inherited (Swierenga et. al., 1991). Mitotic and replication indexes are used as indicators of insufficient cell proliferation biomarkers. Rojas et al. (1993) suggested that cell proliferation kinetics and mitotic index measurements are useful for the prescribing of drugs with potential cytostatic activity. Some medicinal herbs show cytotoxic effect, evidenced by the decrease of the mitotic index (Gadano et al., 2006).

The MNPCEs in young erythrocytes arise primarily from chromosome fragments that are not incorporated into the daughter nuclei at the time of cell division in the erythropoietic blast cells and changes in the incidence of MNPCEs are considered to reflect chromosomal damage (Salamone and Heddle, 1983).

In the micronucleus formation, when a bone marrow erythroblast develops into a PCE, the main nucleus is extruded; any micronucleus that has been formed may remain behind in the otherwise anucleated cytoplasm. Visualization of micronuclei is facilitated in these cells because they lack a main nucleus. They provide a quantifiable measure of recent DNA injury that result from acentric fragments or whole chromosomes left behind the main nucleus at telophase. An increase in the frequency of micronucleated polychromatic erythrocytes (MNPCEs) in treated animals is an indication of induced chromosomal damage (Mavournin et al., 1990; OECD 474, 1997; Gonsebatt et al., 1997; Mahata et al., 2003).

To the best of our knowledge, this is the first study to investigate the effects of this plant using chromosomal aberrations test and micronucleus assay. Determination of the genotoxic/non-genotoxic effects of this plant in an in vivo system is important not only to prove its safety, but also to assess the potential risks when combined with pharmacologic drugs. In our previous study, we concluded that the methanolic extract of Caralluma acutangula possess anticancer properties in vitro against hepatocellular carcinoma HEPG2 cell line and breast carcinoma MCF-7 cell line (Al-Faifi et al., 2016). In the current study, the $C$. acutangula extract was evaluated for genotoxic potential by means of chromosomal aberrations assay and micronucleus test in mice bone marrow cells in vivo. The extract did not significantly increase the number of structural chromosomal aberrations. No significant differences in the percentages of 
mitotic indices were observed at the three different concentrations of $C$. acutangula extract. In micronucleus test, the extract caused no significant increase in the number of micronucleated polychromatic erythrocytes or in the mean ratio of polychromatic to total erythrocytes indicating non clastogenicity. In light of these results, the methanolic extract of $C$. acutangula does not show genotoxic effects on mice bone marrow cells in vivo.

\section{REFERENCES}

1. Abdel-Sattar E, Ahmed AA, Hegazy ME, Farag MA, Al-Yahya MA. Acylated pregnane glycosides from Caralluma russeliana. Phytochemistry, 2007; 68: 1459-1463.

2. Adler, I.D. (1984). Cytogenetic Tests in Mammals. In: Venitt, S. and Parry, J.M. (eds). Mutagenicity Testing: a Practical Approach. pp 275-306. Oxford IRL Press.

3. Ahmad MM, Qureshi S, Shah A, Qazi NS, Rao RM, Al-Bekairi AM. Anti-Inflammatory activity of Caralluma tuberculata alcoholic extract. Fitoterapia, 1983, 46: 357-360.

4. Al-Azzawi AM. Genotoxic and cytotoxic study of Tecoma stans Bignoniaceae. Pak J Biol Sci, 2012; 15(2): 92-97.

5. Albalawi MAD, Bashir NAO and Tawfik A. Anticancer and Antifolate Activities of Extracts of Six Saudi Arabian Wild Plants Used in Folk Medicine. Journal of life Sciences, 2015; 9:334-340

6. Al-Faifi ZIA, Masrahi YS, Aly MS, Turki A. In vitro Anticancer Activity of Caralluma acutangula (Decne.) N.E.Br. Extract. Int. J. Pharm. Sci. Rev. Res., 2016; 38(2): 59-63.

7. Al-Harbi MM, Qureshi S, Reza M, Ahmed MM, Afzal M, Shah AH. Evaluation of Caralluma tuberculata pretreatment for the protection of rat gastric mucosa against toxic damage. Toxicol. Appl. Pharmcol., 1994; 128, 1.

8. Attia SM. The genotoxic and cytotoxic effects of nicotine in the mouse bone marrow. Mutat. Res., 2007; 632: 29-36.

9. Attia SM. The genotoxic and cytotoxic effects of nicotine in the mouse bone marrow. Caryologia 2011; 64(4):365-369.

10. Celik A, Mazmanci B, CamlicaY, Askin A (2003). Cytogenetic effects of lambda-cyalothrin on Wistar rats bone marrow. Mutat. Res. 539: 91-97.

11. Chakrabati CS. Genotoxic effects of Euphoratorium extract on the bone marrow chromosomes of rat (Rattus norvegicus). Proc Zool Soc Calcutta, 2001; 54: 22-26.

12. Chaudhary S. Flora of the Kingdom of Saudi Arabia. National Agriculture and Water Research Center, Riyadh, 2001; 2.

13. Deepak D, Srivastav S, Khare A. Pregnane Glycosides. Prog. Chem. Org. Nat. Prod., 1997; 71: 169.

14. Dutt H, Singh S, Avula B, Khan I, Bedi Y. Pharmacological review of Caralluma R.Br. with special reference to appetite suppression and anti-obesity. J. Med. Food, 2011; 15(2): 108-119.

15. Gadano A, Gurni AA, Carballo MA Argentine folk medicine: Genotoxic effects of Chenopodiaceae family. J. Ethnopharmacol., 2006; 103(2): 246-51.

16. Gonsebatt ME, Vega L, Salazar AM, Montero R, Guzman P, Blas J, et al. Cytogenetic effects in human exposure to arsenic. Mutat Res 1997; 386(3): 219-228.

17. Hagmar, L \& Brøgger, A \& L Hansteen, I \& Heim, Sverre \& Högstedt, B \& Knudsen, Lisbeth \& Lambert, Bo \& Linnainmaa, K \& Mitelman, F \& Nordenson, I. (1994). Cancer risk in humans predicted by increased levels of chromosomal aberrations in lymphocytes: Nordic study group on the health risk of chromosome damage. Cancer research. 54. 2919-22.

18. Hayashi M, Sofuni T, Ishidate M Jr. Kinetics of micronucleus formation in relation to chromosomal aberrations in mouse bone marrow, Mutat. Res., 1984, vol. 127 (pg. 129 - 137) 
19. Ishidate M Jr, Harnois MC, Sofuni T (1988) A comparative analysis of data on the clastogenicity of 951 chemical substances tested in mammalian cell cultures. Mutat Res 195: 151-213.

20. Khan SW and Khatoon S, Ethnobotanical studies on some useful herbs of Haramosh and Bugrote valleys in Gilgit, northern areas of Pakistan. Pak. J. Bot., 2008; 40:43

21. Lawrence RM, Choudhary S, Caralluma fimbriata in the treatment of obesity. In Proceedings of the $12^{\text {th }}$ Annual World Congress of Anti-Aging Medicine, Las Vegas, USA, 2004.

22. Mahata J, Basu A, Ghoshal S, Sarkar JN, Roy AK, Poddar G, et al. Chromosomal aberrations and sister chromatid exchanges in individuals exposed to arsenic through drinking water in West Bengal, India. Mutat Res 2003; 534(1-2): 133-143.

23. Mavournin KH, Blakey DH, Cimino MC, Salamone MF, Heddle JA. The in vivo micronucleus assay in mammalian bone marrow and peripheral blood. A report of the US Environmental Protection Agency Gene-Tox Program. Mutat. Res. 1990; 239(1): 29-80.

24. Morita T, Asano N, Awogi T, Sasaki Y, Sato S, Shimada H, et al. Evaluation of the rodent micronucleus assay in the screening of IARC carcinogens (groups 1, 2A and 2B). The summary report of the 6th collaborative study by CSGMT/JEMS MMS (collaborative study of the micronucleus group test mammalian mutagenicity study group). Mutat Res. 1997; 389: 3-122.

25. Norppa, H., Bonassi, S., Hansteen, I.L., Hagmard, L., Stromberg, U., Rossner, P., Boffetta, P., Lindholm, C., Gundyi, S., Lazutka, J., Cebulska-Wasilewskak, A., Fabianova, E., Sramf, R.J., Nudsenm, L.E., Barale, R., Fucic, A., 2006. Chromosomal aberrations and SCEs as biomarkers of cancer risk. Mutat. Res. 600, 37-45. (IVSL).

26. OECD 474. Mammalian erythrocyte micronucleus test. In: OECD guideline for the testing of chemicals. 1997.

27. Priya D, Rajaram K, Sureshkumar P. Evaluation of Anticancer Activity of Methanolic Extract of Caralluma Fimbriata Wall. Against Lung Cancer Cell Line. World Journal of Pharmacy and Pharmaceutical Sciences. 2014; 3(4): 1263-1271.

28. Preston RJ, Dean BJ, Gallowey S, Holden H, McFee AF, Shelby M. Mammalian in vivo cytogenetic assays: analysis of chromosome aberrations in bone marrow cells. Mutat Res. 1987; 189: 157-165.

29. Rahman MA, Mossa JS, Al-Said MS, Al-Yahya MA. Medicinal plant diversity in the flora of Saudi Arabia 1: a report on seven plant families. Fitoterapia, 2004; 75(2): 149-161,

30. Ramesh M, Rao YN, Kumar MR, Rao AVN, Prabhakar MC, Reddy BM. Antinociceptive and antiinflammatory activity of carumbelloside-I isolated from Caralluma umbellata. J. Ethnopharmacol., 1999; 68(1-3): 349-52.

31. Rao RM, Rao YN, Rao AV, Prabhakar MC, Reddy BM, Antinoceptive and anti-inflammatory activity of flavonoids isolated from Caralluma attenuata, J. Ethanopharmacol., 1998; 62(1): 63-66.

32. Rojas E, Herrera LA, Sordo M, Gonsebatt ME, Montero R, Rodriguez R, et al. Mitotic index and cell proliferation kinetics for identification of antineoplastic activity. Anticancer Drugs, 1993; 4(6): 63740.

33. Robinson MM and Zhang X. The world medicines situation 2011 (WHO, 2011)

34. Salamone MF and Heddle JA. The Bone Marrow Micronucleus Assay: Rationale for a Revised Protocol, 1983; Chemical Mutagens. 111-149. 10.1007/978-1-4613-3694-5-4.

35. Sánchez P, Llorente MT, Castaño A. Flow cytometric detection of micronuclei and cell cycle alterations in fish-derived cells after exposure to three model genotoxic agents: mitomycin C, vincristine sulfate and benzo(a)pyrene. Mutat. Res. Volume 465, Issues 1-2, 16 February 2000, Pages $113-122$

36. Schmid W, The micronucleus test. Mutat Res, 1975; 31: 9-15. 
37. Shetty PD, D'Souza UP, Prasanna SK. Genotoxic studies of Memecylon umbellatum leaves. Int J Pharm \& Health Sci, 2010; 1(2): 45- 49.

38. Sutiakova, I., Kovalkovic ova, N., Sutiak, V., (2012). Chromosomal aberrations in ovine lymphocytes exposed in vitro to tolylfluanid. J. Environ. Sci. Health B. 47, 1-6.(IVSL).

39. Swierenga SH, Heddle JA, Sigal EA, Gilman JP, Brillinger RL, Douglas GR, Nestmann ERv. Recommended protocols based on a survey of current practice in genotoxicity testing laboratories, IV. Chromosome aberration and sister-chromatid exchange in Chinese hamster ovary, V79 Chinese hamster lung and human lymphocyte cultures. Mutat. Res. 1991; 246(2): 301-22.

40. Tatiya AU, Kulakarni AS, Surana SJ, Bari ND. Antioxidant and hypolipidemic effect of Caralluma adscendens Roxb. in alloxanized diabetic rats. Int. J. Pharmacol., 2010; 6(4): 362-368.

41. Venktesh S, Reddy GD, Reddy BM, Ramesh M, Rao AVNA. Antihyperglycemic activity of Carulluma asttenuata. Fitotherapia., 2003; 74: 274-7.

42. Wadood A, Wadood N, Shah SA. Effects of Acacia arabica and Caralluma edulis on blood glucose levels of normal and alloxan diabetic rabbits. J. Pak. Med. Assoc., 1989; 39(8): 208-12.

43. Zakaria MNM, Islam MW, Radhakrishanan R, Chen HB, Kamil M, Al-Gifri A, Chan K, Al-Attas A. Anti-nociceptive and anti-inflammatory properties of Caralluma arabica. J. Ethnopharmocol., 2001; 76(2): 155-158.

44. Zakaria MNM, Islam MW, Radhakrishman R, Liu XM, Ismail A, Kamil M, Chan K, Al-Attas A. Anti-gastric ulcer and cytoprotective properties of Caralluma arabica. Pharmaceutical Biology, 2002; 40: $225-230$.

45. Zhong Y, Feng SL, Luo Y, Zhang GD, Kong ZM. (2001). Evaluating the Genotoxicity of Surface Water of Yangzhong City Using the Vicia Faba Micronucleus Test and the Comet Assay. Bulletin of environmental contamination and toxicology. 67. 217-24. 10.1007/s001280113. 